\title{
Microbial-faunal interactions in the rhizosphere and effects on plant growth ${ }^{\S}$
}

\author{
Michael Bonkowski ${ }^{a *}$, Weixin Cheng ${ }^{\mathrm{b}}$, Bryan S. Griffiths ${ }^{\mathrm{c}}$, Jörn Alphei ${ }^{\mathrm{d}}$, Stefan Scheu ${ }^{\mathrm{a}}$ \\ ${ }^{\text {a }}$ Fachbereich 10, Biologie, Technical University Darmstadt, Schnittspahnstr. 3, 64287 Darmstadt, Germany \\ b Department of Environmental Studies, University of California, Santa Cruz, CA 95064, USA \\ c Soil Plant Dynamics Unit, Scottish Crop Research Institute, Invergowrie, Dundee DD2 5DA, UK \\ d Abteilung Ökologie, Inst. f. Zoologie u. Anthropologie, Universität Göttingen, Berliner Str. 28, \\ 37073 Göttingen, Germany
}

Received 10 November 1999; accepted 2 October 2000

\begin{abstract}
Nutrient acquisition by plants occurs in an environment characterized by complex interactions between roots, micro-organisms and animals, termed the rhizosphere. Competition for mineral elements in this sphere is high. The rhizosphere processes are driven by photosynthetically fixed carbon released by roots either directly to mycorrhizal fungal symbionts or as exudates fuelling a wider spectrum of organisms, mainly bacteria. In particular, the role of the soil fauna interacting with rhizosphere micro-organisms and plant roots has so far found little attention. We present evidence that the interaction between plant roots, root exudates and micro-organisms can only be understood in relation to soil faunal activity, indicating that the soil fauna has an important function in regulating rhizosphere microbial processes and therefore significantly affects plant growth. (C) 2000 Éditions scientifiques et médicales Elsevier SAS
\end{abstract}

rhizosphere / microbial activity / soil biota / food web interactions / plant growth

\section{INTRODUCTION}

\subsection{Microbial activity in the rhizosphere}

Microbial activity in soil is generally thought to be limited by the availability of carbon [3], except in the rhizosphere where there is a constant supply of readily available carbon sources to the heterotrophic microflora [21, 22]. Due to the excess C supply, microbial activity and biomass in the rhizosphere of plants differ considerably from non-rhizosphere soil.

In a laboratory experiment, Alphei et al. [2] separated the rhizosphere soil of wood-barley (Hordelymus europaeus L.) from the neighbouring soil with a

\footnotetext{
$\S$ Paper presented at the 16th World Congress of Soil Science, 20-26 August 1998, Montpellier, France.

* Correspondence and reprints.

E-mail address: bonkow@ bio.tu-darmstadt.de (M. Bonkowski).
}

45- $\mu \mathrm{m}$ gauze and found that the microbial biomass in the rhizosphere was almost doubled compared to the two adjacent $3 \mathrm{~mm}$ wide compartments without roots (table I). Microbial respiration was also higher in soil near roots than in soil away from roots (rhizosphere soil $>$ intermediate soil $>$ bulk soil). Similarly, in studies on the rhizosphere continuum of crop plants, the microbial biomass $\mathrm{C}$ was highest at the rhizoplane and declined outward [22] (figure 1).

Given a selective stimulation of micro-organisms in the rhizosphere, what is the role of these rhizospheric populations in nutrient cycling and plant growth? How may plants benefit from releasing $\mathrm{C}$ resources into the rhizosphere? By exudating large amounts of carbon to the soil, plants apparently waste photosynthate which might have been used for growth.

\subsection{Effects of microbial grazers on mineralization processes}

Early studies by Coleman and co-workers [4, 28, 31, $32,43,132]$ showed that nutrients added to the soil 
Table I. Comparison of rhizosphere soil and two subsequent neighbouring $3 \mathrm{~mm}$ wide non-rhizosphere soil compartments without roots in respect to microbial biomass, basal respiration, average number of protozoa, amoebae, flagellates and ciliates and average number of nematodes in a laboratory experiment investigating the effects of protozoa, bacterial feeding nematodes and earthworms on plant growth of wood-barley (Hordelymus europeus L. [2]).

\begin{tabular}{|c|c|c|c|c|}
\hline & Units & $\begin{array}{c}\text { Rhizosphere } \\
\text { 0-6 mm }\end{array}$ & $\begin{array}{c}\text { Intermediate } \\
6-9 \mathrm{~mm}\end{array}$ & $\begin{array}{l}\text { Non-rhizosphere } \\
9-12 \mathrm{~mm}\end{array}$ \\
\hline Microbial biomass & $\mu \mathrm{g} \mathrm{C}_{\text {mic }} \cdot \mathrm{g}^{-1}$ & 1030 & 680 & 590 \\
\hline Basal respiration & $\mu \mathrm{L} \mathrm{O}_{2} \cdot \mathrm{g}^{-1} \cdot \mathrm{h}^{-1}$ & 7.4 & 4.6 & 4.1 \\
\hline Protozoa & ind. $g^{-1}$ & 38900 & 16700 & 13500 \\
\hline Amoebae & ind. $g^{-1}$ & 18400 & 4900 & 2000 \\
\hline Flagellates & ind $\cdot g^{-1}$ & 9400 & 3800 & 5800 \\
\hline Ciliates & ind $\cdot g^{-1}$ & 5100 & 2900 & 2200 \\
\hline Nematodes & ind $\cdot g^{-1}$ & 49 & 43 & 44 \\
\hline
\end{tabular}

were rapidly immobilized by rhizosphere bacteria (Pseudomonas sp.) with only small amounts returned to the soil after carbon supply ceased. However, mineralization in terrestrial systems is not only due to the activity of micro-organisms. The constant supply of carbon compounds from plant roots fuels complex interactions among rhizosphere organisms including those between micro-organisms and plants, among micro-organisms, between animals and microorganisms, between animals and plants, and among animals. As shown recently, even above-ground herbivory may significantly affect rhizosphere food-web processes by increasing the allocation of carbon from grazed plants to the rhizosphere $[8,62]$. The outcome of these interactions may be either positive (e.g.

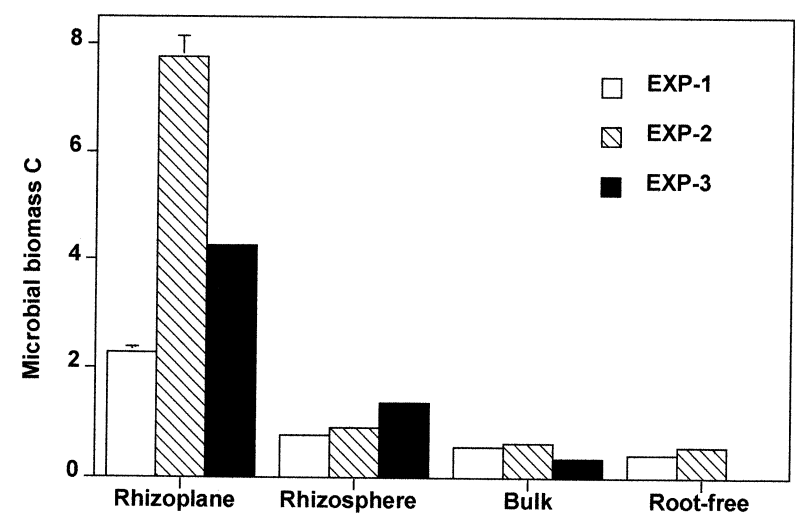

Figure 1. Microbial biomass $\mathrm{C}\left(\mathrm{mg} \mathrm{C} \cdot \mathrm{g}^{-1}\right.$ soil dry wt) measured by using substrate-induced respiration method $[19,20]$ in rhizosphere continuums of three experiments. Experiment 1: membrane column with wheat; experiment 2 : membrane cell with wheat; experiment 3 : field-grown corn. Detailed descriptions of the materials and methods are given by Cheng et al. [22]. mutualistic, associative) or negative (e.g. predatory, competitive) [9]. Negative effects of rhizosphere animals (e.g. rhizophagous species, especially plant parasitic nematodes) have been the subject of much research $[48,104,115,133]$. We will focus here on those interactions that determine whether the microbial activity in the rhizosphere increases or decreases the availability of mineral nutrients for higher plants. However, it should be noted that root-feeding by nematodes may increase allocation of carbon belowground and increase significantly the leaking of $\mathrm{C}$ from roots. Therefore, root-feeding nematodes may also stimulate rhizosphere microbial processes $[8,66$, 67, 116].

Protozoa and microbial feeding nematodes are known to be the most important grazers of the microflora in terrestrial ecosystems $[7,27,36,64,68]$. In the presence of microfauna, soil respiration and specific respiration (i.e. the ratio of total microbial biomass to basal respiration of the active biomass) has been found to be increased $[2,10,79]$. Protozoa are considered to be effective bacterial predators because of their high turnover rates and high numbers in rhizosphere soil $[34,42,135]$. Thus, concomitant with an increase in microbial turnover in the presence of microfauna $[2$, $31,32]$ grazing on microflora may result in a decrease in bacterial numbers. This was demonstrated for the rhizosphere of $H$. europaeus where the respiratory inhibition by streptomycin was reduced by $20 \%$ in presence of protozoa, indicating a selective grazing of protozoa on soil bacteria [2]. Significant effects on nutrient cycling demonstrated the relevance of protozoan grazing in this experiment. The amount of nitrate in leaching water from microcosms increased more than ten-fold in treatments with protozoa, and further increased by a factor of 1.2 when earthworms were present [2].

Generally, as shown by controlled studies of microflora-microfauna interactions, the addition of protozoa leads to an increased mineralization in soil $[2,31,51,126,132]$, whereas the effects of bacterial 
feeding nematodes appear to depend on the status of the populations with nutrients released only if nematode populations decline $[4,11,132]$ or in presence of nematode predators [14].

\section{MICROFLORA-FAUNA INTERACTIONS AND EFFECTS ON PLANT GROWTH}

Plant growth depends on light, moisture and available nutrients. The nutrient availability in the rhizosphere may directly be influenced by plant roots. The mechanisms include changes in rhizosphere $\mathrm{pH}$ induced by root metabolism, and it is assumed that organic acids and non-protein amino acids in root exudates directly contribute to plant element uptake by chelating trace elements such as Fe, Mn and $\mathrm{Zn}$ [84]. However, due to the simultaneous release of energy sources by roots, nutrients in the rhizosphere are taken up rapidly by soil bacteria. Thus, grazing of the microflora by microbivores seems to be a crucial mechanism to maintain the balance in the competition between micro-organisms and plants.

The presence of protozoa has been shown to increase plant growth significantly [135]. When nitrate and glucose was added to pots containing a sandy soil with ryegrass, $75 \%$ of the nitrate was lost by leaching when no glucose was added, whereas with glucose addition only $20 \%$ nitrate was lost, probably due to nitrate assimilation by micro-organisms [105]. As a result of protozoan grazing on the micro-organisms, the ryegrass plants were able to assimilate $44 \%$ of this immobilized N. Thus, plant roots were effective in competing for $\mathrm{N}$ released due to protozoan grazing [105]. In presence of protozoa, the amount of shoot $\mathrm{N}$ was found to be increased by $18-137 \%$ [43], 12-48 \% [24, 25], $21 \%$ [76], 19-30\% [79], 6-38\% [77] and $40-45 \%$ [71] in laboratory experiments. The increased amount of $\mathrm{N}$ in plants was accompanied by an increase in plant biomass by $30-80 \%$, and therefore concentrations of nitrogen were reduced in most studies $([2,24,25,71,77,79]$; figure 2$)$ and the amount of $\mathrm{N}$ in plants was even found to be reduced in presence of protozoa [77]. Thus, increased nutrient uptake by plants may not have been the cause, but the consequence of increased plant growth. Effects of bacterial feeding nematodes have been found to be similar to those of protozoa, but less pronounced [2]. This is probably due to the comparatively smaller reproductive rate of nematodes and the ability of protozoa to feed on bacteria in soil pores inaccessible to nematodes [53].

Despite the crucial importance of interactions between roots (root exudates), micro-organisms and their predators for plant growth, knowledge of these interactions is still fragmentary and the mechanisms are poorly understood [135]. Five topics might be distin-
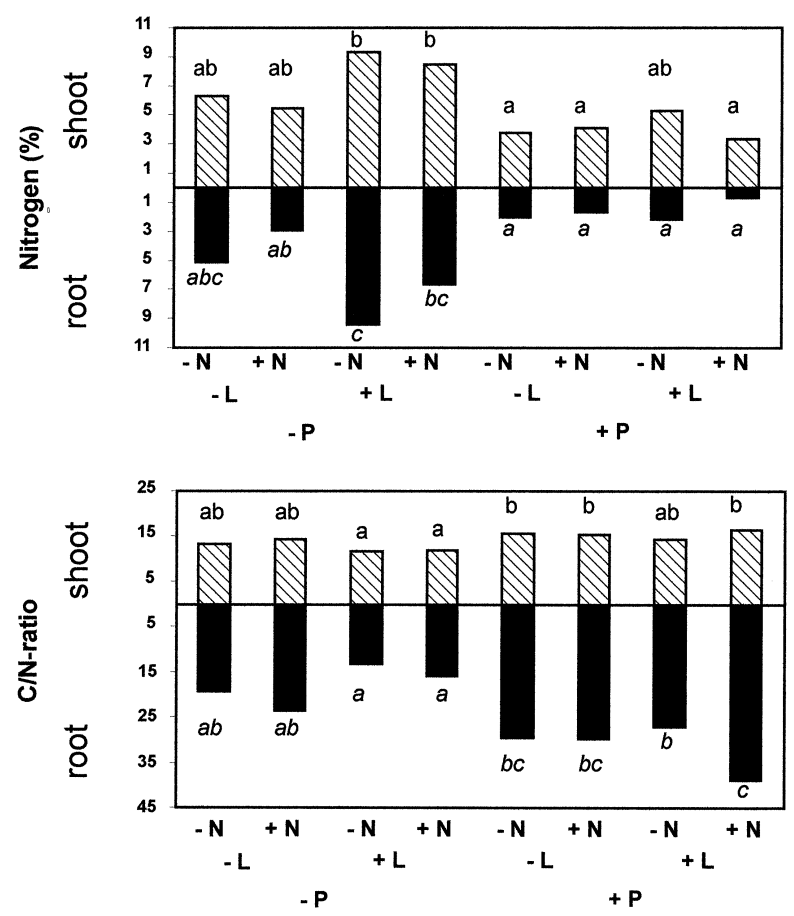

Figure 2. Effects of nematodes, earthworms and protozoa on concentration of nitrogen and $\mathrm{C} / \mathrm{N}$-ratio in shoots and roots of wood barley ( $\mathrm{N}$, nematodes; L, earthworms; P, protozoa; -, without; +, with). Bars with different letters are significantly different (Tukey's MSD test, $P \leq 0.05)$. Data from Alphei et al. [2].

guished: bacteria-microfauna interactions, changes in the microbial community structure, hormonal effects, fungi-fauna interactions and fauna-fauna interactions.

\subsection{Bacteria-microfauna interactions}

Considering that most studies reported that nitrogen mineralization and subsequently the $\mathrm{N}$ transfer to plants increased in the presence of microbial grazers, increased plant growth in the presence of microbivores has been generally explained by direct nutrient effects due to microfaunal grazing on rhizosphere bacteria i.e. the 'microbial loop' ([27], figure 3).

Protozoa and their bacterial prey presumably differ little in respect to their $\mathrm{C}: \mathrm{N}: \mathrm{P}$ ratios, but protozoa use only $10-40 \%$ of the prey carbon for biomass production, the excess $\mathrm{N}$ and $\mathrm{P}$ is assumed to be excreted in inorganic form and may therefore be readily available for other soil organisms including plant roots [53, 135]. In addition, protozoan populations in soil fluctuate through time $[23,70]$ and parallel to the decline in protozoan numbers large amounts of rapidly decomposable protozoan tissue may enter the detrital foodweb. According to Foissner [47], more than two-thirds of soil animal respiration can be attributed to protozoa. The accompanied high production rates of protozoa 


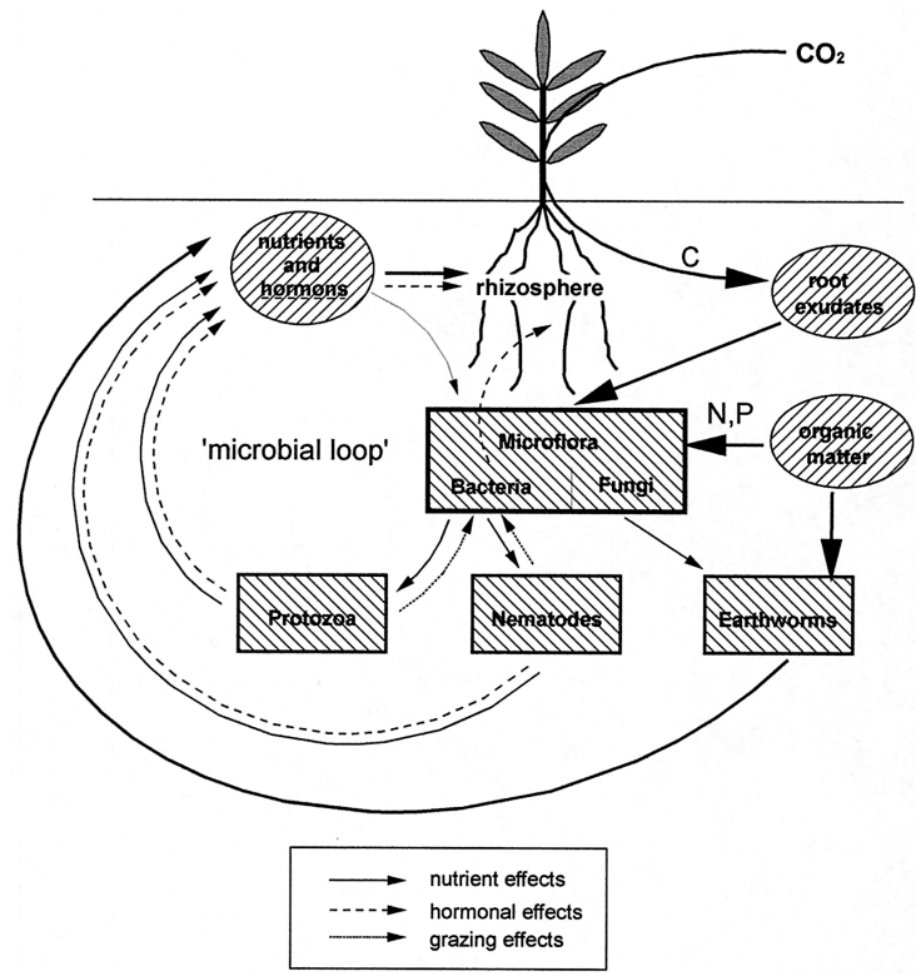

Figure 3. A conceptual model illustrating possible mechanisms of microfaunal grazing on rhizosphere bacteria and effects of endogeic earthworms on plant performance (related to an experiment by Alphei et al. [2]). Earthworms affected plant growth mainly by nutrient effects. Microfaunal grazing may affect plant growth (i) via nutrient effects by releasing $\mathrm{NH}_{4}$ from consumed rhizosphere bacteria, i.e. the 'microbial loop'; (ii) by release of phytohormones due to microbial grazing; (iii) by grazing-mediated changes in the composition of the microbial community. Fauna-fauna interactions, plant-mycorrhiza interactions and fauna-fungus interactions are not considered in this scenario. suggest significant effects on nutrient mineralization due to grazing on bacteria.

Bacteria mineralize $\mathrm{N}$ from soil organic matter and calculations by Clarholm [25, 26] gave evidence that protozoan grazing results in the release of this additional N. Using [ $\left.{ }^{15} \mathrm{~N}\right]$-labelled bacteria, Kuikman et al. [78] and Kuikman and Van Veen [76] confirmed that grazing by protozoa increases the availability of nitrogen to plants originating from bacterial cells but also from soil organic matter. Clarholm [26] argued, that when no $\mathrm{N}$ is lost by exudation, the readily available carbon compounds in root exudates stimulate growth of dormant microbial populations along the root tip, resulting in mineralization of nitrogen from the soil organic matter and subsequent incorporation of $\mathrm{N}$ into microbial biomass. She assumed that the uptake of nitrogen from soil organic matter by rhizosphere bacteria and the subsequent release of these nutrients from bacteria due to grazing by protozoa and nematodes is of significant importance for plant growth. However, there is evidence that the microbial loop is insufficient for explaining the protozoan-mediated stimulation of plant growth. By including the amount of nitrogen lost through exudation and modelling $\mathrm{N}$ transformations in the rhizosphere, Robinson et al. [106] and Griffiths and Robinson [55] concluded that rhizosphere bacteria do not use plant-derived carbon to mineralize soil organic nitrogen to any great extent.

\subsection{Grazing-mediated changes in the microbial community structure}

The stimulation of plant growth in the presence of protozoa may be due to indirect effects since protozoan grazing on the rhizosphere microflora results in significant changes in the composition of the microbial community [130] and associated soil biological processes $[103,125]$. Protozoa and nematodes are known to feed selectively on certain species of bacteria [17, $53,118,123]$ and it has been demonstrated for flagellates, amoebae and ciliates, that they specifically stimulate nitrifying bacteria $[2,52,124]$ indicating that protozoan grazing facilitates the establishment of certain bacterial species. Additionally, Griffiths and Bardgett [54] using the $\mathrm{BIOLOG}^{\circledR}$ system detected profound changes in the metabolic diversity of microorganisms decomposing plant residues in a liquid culture system, when the cultures were inoculated with the cilitate Tetrahymena pyriformis. This finding was recently confirmed in a soil system [56] by studying the effects of bacterial feeding nematodes, protozoa or a combination of nematodes and protozoa on the structure of the rhizosphere microbial community. The extraction of bacterial DNA revealed that protozoa changed the composition of the bacterial population in the rhizosphere, and phospholipid fatty acids showed that $\mathrm{Gram}^{+}$bacteria were increased while $\mathrm{Gram}^{-}$ 
bacteria were decreased in treatments with protozoa. These changes were linked with distinct shifts in the metabolic diversity of the microbes assessed by $\mathrm{BIOLOG}^{\circledR}$. Thus, there is increasing evidence that microbial grazers, particularly protozoa, are able to alter the composition and the functioning of the rhizosphere microbial community (figure 3). Roots support a community of bacteria in which some populations are able to produce trace amounts of growth regulators which can markedly affect plant growth either positively or negatively $[12,13,86]$. Hence, grazing by protozoa may alter the composition of the rhizosphere microflora from unfavourable micro-organisms towards a plant growth-promoting rhizosphere community [15].

\subsection{Hormonal effects}

Early studies by Nikolyuk and Tapilskaja [92, 93] have shown that soil amoebae grown axenically with the bacterium Azotobacter are able to release phytohormones into the growth medium. Production of indolyl-3-acetic acid related substances was at a maximum in 75-d-old amoebal cultures and the biomass of pea seedlings grown in culture fluid from amoebae increased by $48 \%$ [117]. In contrast, culture fluid of Azotobacter increased biomass of pea seedlings only by $3-4 \%$. Thus protozoa may directly stimulate plant growth by hormonal effects (figure 3).

Jentschke et al. [71] presented further evidence for non-nutritional effects of protozoa on plant growth. By diminishing nutrient effects in a sand culture system by continuously supplying nutrients in surplus, they found an increased biomass of spruce seedlings by $50-60 \%$ in the presence of protozoa. If plant growth is limited by the availability of nutrients, an increased nutrient mobilization in presence of protozoa should translate to increased plant tissue concentrations of the limiting element which most often is nitrogen. Conversely, Jentschke et al. [71] found plant tissue concentrations of $\mathrm{N}$ in treatments with protozoa to be lower than in treatments with bacteria and fungi only. In addition, in the presence of protozoa spruce seedlings had a more branched root system with more and finer roots. Thus, the increased total $\mathrm{N}$ uptake per plant in the presence of protozoa may not have been the cause but the result of improved plant and root growth.

Of course, experimental evidence linking protozoan-mediated hormonal effects to plant growth is still very limited. We have neither information on the ability of different protozoan groups in releasing plant growth regulating substances, nor on the specific nature of the substances produced and the mechanisms involved. Protozoa may directly release hormonal active substances as waste- or by-products from bacterial remains during predation. However, since many soil bacteria release plant hormones as a result of gaining metabolic energy from the transformation of hormonal precursors (e.g. tryptophan, [109]), it is also possible that hormonal precursors are released by protozoa and are transformed into hormonal active substances by micro-organisms.

It seems that the view of scientists in the past was too much focused solely on nutrient effects by microfaunal grazing. Nutrient effects appear to be insufficient to explain the multitude of protozoan-mediated changes in plant performance. Also, parameters like microbial and plant biomass are insufficient to reflect the specific changes in the microbial community structure as well as in plant performance. Future experiments should focus more specifically on changes in the soil microbial community structure and plant morphology in order to disentangle the complex bacterial-faunal interactions in the rhizosphere.

\subsection{Fungi-fauna interactions in the rhizosphere}

Most terrestrial plants live in symbiosis with mycorrhizal fungi, spending a significant part of their carbon resources for trading with fungi for nutrients, especially phosphorus [1, 37]. The biomass of ectomycorrhiza in a coniferous forest has been estimated to be about $6 \%$ of that of trees [46] and the biomass of vesicular-arbuscular-mycorrhizal fungi was estimated to be $5-20 \%$ of that of roots [113] indicating that the mycorrhizal associations with plants account for a substantial part of the carbon allocated below-ground. Although mycorrhizal fungi play a key role in rhizosphere processes [57, 114], and despite the fact that soil fauna contains many fungivorous species, surprisingly little is known on faunal-mycorrhizal interactions $[29,44,45,100]$.

\subsubsection{Mesofauna-fungi interactions}

Collembola and oribatid mites are known to feed selectively on certain soil fungi [74, 87] and it is therefore likely that the fungal community in the field is subject to a selective feeding pressure by soil microarthropods. This may either reduce fungal biomass or stimulate growth of the less preferred species due to a reduced competition between fungal species [45]. Although microarthropods are known to selectively feed on certain ectomycorrhizal fungi $[61,119]$, mycorrhizal fungi are generally considered not to be the preferred food source of Collembola and oribatid mites [74]. However, fungal feeding microarthropods also detrimentally affect the hyphal network by severing hyphal branches at their bases even when offered a greater range of fungi as food sources [75]. The infection rate by arbuscular mycorrhiza and therefore plant growth was found to decrease with increasing collembolan density in pot experiments $[44,58,81$, $85,88,129]$. Microarthropod densities in laboratory experiments are often unnaturally high and moderate 
arthropod grazing which may be closer to what occurs in the field, has been shown to stimulate mycorrhizal growth $[40,44,85,90]$. Therefore, it is difficult to relate laboratory findings to the field situation. The application of biocides in a field experiment resulted in higher shoot yield and $\mathrm{P}$ concentrations in plants [44, 88 ], and gave evidence that the reduction in microarthropod numbers improved mycorrhizal function. Conversely, addition of Collembola in a field experiment was associated with a $40 \%$ higher mycorrhizal infection and a $5 \%$ increase in leaf tissue $\mathrm{N}$ concentrations of soybean [85]. Thus, field and laboratory experiments gave evidence that fungivorous microarthropods may influence plant growth via grazing on mycorrhizae, but the relevance of microfauna grazing is still under debate. McLean et al. [89] suggested that the impact of microarthropods on the fungal community is low. Fitter and Sanders [45] found evidence that interactions between microarthropods and fungi may only be important at certain life stages of a plant (e.g. flowering) when the P demand is high. Enchytraeids which are also assumed to feed on soil fungi may reach high numbers in soils $[35,39]$. However, we are not aware of any data on food preferences of enchytraeids for certain fungal species or on the impact of enchytraeids on mycorrhizae or plant growth.

\subsubsection{Microfauna-fungi interactions}

Most studies on microfauna-mycorrhizae interactions deal with plant parasitic nematodes which may affect the yield of crop plants and are therefore of economic interest $[34,73]$. The nematodes interacting with mycorrhizae include both, fungal (i.e. hyphal) feeders and obligate plant root parasites. Fungal feeding nematodes may reduce the number of hyphae of mycorrhizal fungi extending from the root surface and this has been demonstrated to reduce plant yield [65]. Giannakis and Sanders [49] reported that Aphelenchoides composticola reduced plant yield and phosphorus content of shoots of the VAM mycorrhizal Trifolium pratense presumably by feeding on mycorrhizal hyphae thereby reducing the beneficial effect of mycorrhizae on plant growth. On the other hand, infection with VAM mycorrhizae was found to increase the plant tolerance to nematode endoparasites [120]. Thus, beneficial effects of mycorrhizal fungi on plant growth may compensate for the damage caused by the activity of plant parasitic nematodes $[16,83$, 131]. The mechanisms may be either linked to increased phosphorus and micronutrient uptake [134] or to structural and physiological changes in plant roots following mycorrhizal infection [112] as illustrated by inhibited reproduction of Meloidogyne javanica and Radopholus similis due to increased lignin and phenol contents in mycorrhizal roots $[111,121]$. The relationship between endoparasitic nematodes and mycorrhizal fungi appears to be mutually inhibitory, because mycorrhizal fungi are deterred from colonizing nema-

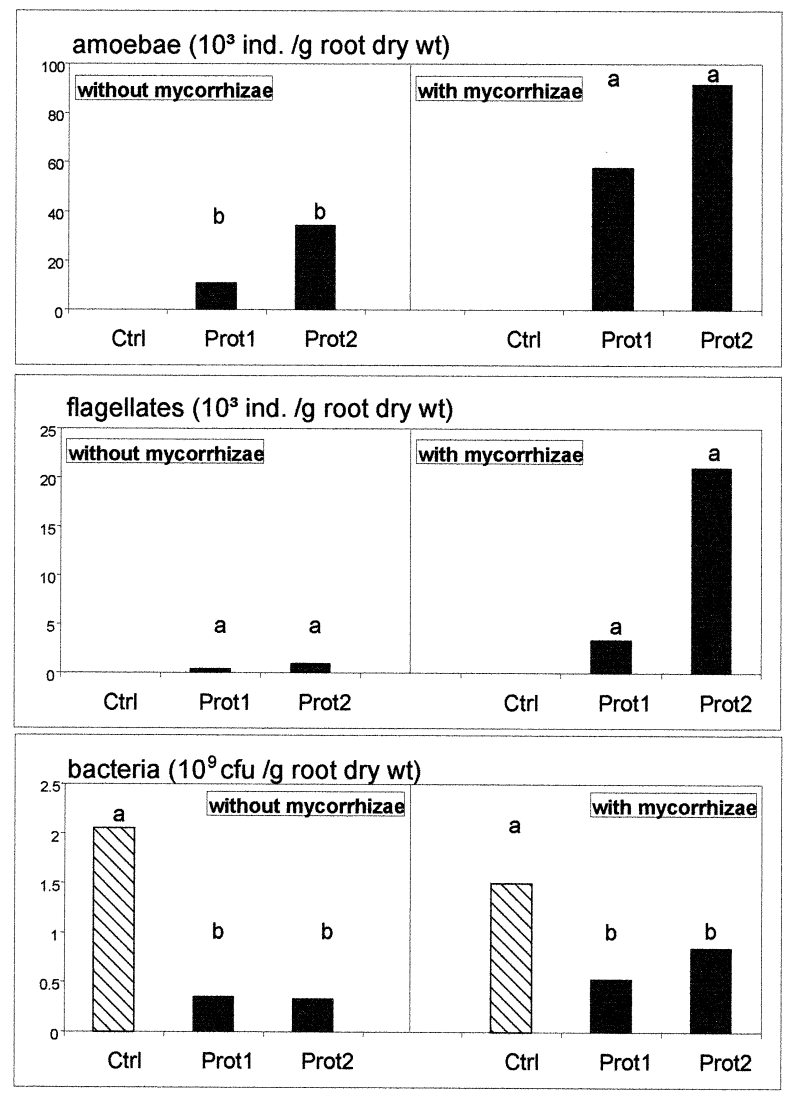

Figure 4. Numbers of naked amoebae, flagellates and bacteria (CFU) extracted from the rhizoplane of non-mycorrhizal and mycorrhizal Picea abies seedlings. Numbers of bacteria are given for the protozoafree control (Ctrl) and for treatments with protozoa from a soil suspension (P1) or from protozoan cultures (P2). Bars with different letters are significantly different (Tukey's MSD test, $P \leq 0.05$ ). Data from Jentschke et al. [71].

tode infected roots and vice versa [65, 134]. In addition to effects on mycorrhiza, plant parasitic nematodes also frequently facilitate the entry of plant pathogenic fungi due to the damaging of cells by feeding activity. This synergistic effect may significantly intensify plant damage [134]. Conversely, saprotrophic fungi have developed different strategies to exploit nematodes either by trapping or by endoparasitism [37] and under certain conditions, this may indirectly reduce plant damage by parasitic nematodes $[69,72]$.

In contrast to nematodes, surprisingly little attention has been paid to protozoan interactions with fungi [103]. Ingham and Massicotte [63] reported that protozoan communities around conifer roots differed from both the host and the ectomycorrhizal fungal species. Jentschke et al. [71] investigated the effects of soil protozoa originating from a soil suspension (P1) or from protozoan cultures (P2) on the growth of Norway spruce seedlings (Picea abies) without mycorrhizae or 
with the ectomycorrhizal fungus Lactarius rufus. In this experiment an array of interactions between mycorrhizae and protozoa occurred. Presence of mycorrhizae affected the colonization of the rhizoplane by protozoa; in particular, the number of naked amoebae at the rhizoplane was increased by factors of 5 (P1) and 3 (P2) (figure 4). The stimulation of protozoan development was due to mycorrhizal colonization per se and did not result from differential seedling growth in mycorrhizal and non-mycorrhizal treatments. Although, numbers of flagellates varied strongly and, therefore, the difference was not statistically significant, the average number of flagellates on the rhizoplane was also increased in mycorrhizal treatments by a factor of 20 [71]. This indicates that protozoa in the rhizosphere significantly interact with mycorrhizae. Parallel to the increase in protozoa, the numbers of bacteria declined indicating that bacterial feeding protozoa dominated in the myco-rhizosphere. These findings are in agreement with increased numbers of amoebae and ciliates in ectomycorrhizal fungal mats reported from a Douglas fir stand [33]. The myco-rhizosphere is colonized by associated bacteria [94] which may also influence mycorrhizal effects on plant growth $[6,80]$. Therefore, the increase in numbers of protozoa of the rhizoplane of spruce seedlings with mycorrhiza found by Jentschke et al. [71] was most likely caused by a mycorrhiza-mediated increase in bacterial numbers and bacterial turnover. However, at the end of the experiment, the number of bacteria at the rhizoplane of mycorrhizal and non-mycorrhizal spruce seedlings was not significantly different. Therefore, the increased density of protozoa at the rhizoplane in mycorrhizal treatments may have also been due to protozoan grazing on mycorrhizal hyphae.

Field investigations by Tapilskaja [117] showed an inverse relationship between the density of protozoa, especially naked amoebae, in rhizosphere soil and the number of cotton plants infected with the cotton wilt fungus Verticillum dahliae. Amoeba albida was isolated from the cotton plant rhizosphere and grown axenically with the bacterium Azotobacter. Laboratory experiments demonstrated that $A$. albida depressed the germination of conidia and microsclerotia of the fungus, and even small numbers of amoebae caused a lysis of the mycelium by producing antibiotic substances, while the fungus did not affect the growth of A. albida [117]. In subsequent field experiments, she found $80 \%$ of the cotton plants to be infected when grown in soil inoculated with $V$. dahliae or $V$. dahliae + Azotobacter, whereas only $20 \%$ of the cotton plants were infected in presence of amoebae [117]. Since fungal growth was successfully suppressed when amoebal numbers exceeded 100 ind. $\mathrm{g}^{-1}$ soil, there is strong evidence that some protozoan species are highly effective in both, regulating fungal communities in soil and therefore modifying fungal effects on plant growth.

In addition to antibiotical effects, the fungal community in soil might be affected by protozoa directly by feeding on fungal spores or hyphae. Indeed amoebae have been found to attack fungal spores or hyphae [5, 59, 95-99]. Chakraborty et al. [18] found evidence that mycophagous amoebae affect root colonization by ectomycorrhizal fungi. However, the ability to perforate hyphae appears to be restricted to a limited spectrum of protozoan species.

Due to culture methods for selecting bacterivore species [47], fungal feeding ciliates [101, 102] and flagellates [60] had been overlooked by protozoologists and were only recently discovered. Ekelund [41] presented evidence that mycophagous flagellates and ciliates are widespread in soil. He added glucose solution to arable soil, which resulted in a 4-fold increase in numbers of mycophagous flagellates and in a 3-fold increase in mycophagous ciliates, suggesting high numbers of fungal feeding protozoa particularly in rhizosphere soil. There is an urgent need for further investigations on protozoan-fungal interactions, since the function of mycophagous protozoa in the soil subsystem may be of significant importance.

\subsection{Fauna-fauna interactions}

A multitude of fauna-fauna interactions occurs in soil as can be supposed by the high diversity of soil organisms $[50,82,108,122]$. Considering that the two major microfaunal phyla, nematodes and protozoa, are constituted of species of various trophic levels, trophic interactions within and between protozoa and nematodes presumably are commonplace. In addition, as shown by the following examples, indirect relationships and omnivory are common characteristics of soil faunal interactions. Therefore, concepts based on trophic guilds only partly reflect the multitude of fauna-fauna interactions in soil.

The addition of 'bacterial' feeding nematodes to soil with protozoa has been found to significantly reduce the number of naked amoebae with a concomitant increase in nematode numbers, indicating that nematodes supposed to be bacterial feeders also consume naked amoebae [4, 43, 132]. Complex interactions between protozoa and nematodes have also been found in the experiment of Griffiths [51], where the bacterial feeding nematode Rhabditis sp. stimulated bacterial production, but was outcompeted for food by the ciliate species Colpoda steinii.

In the study of Alphei et al. [2], an array of interactions between the bacterial feeding nematode Pellioditis pellio and protozoa has been found. In presence of $P$. pellio, the abundance of naked amoebae in non-rhizosphere soil decreased from 3800 to 1000 ind $\cdot \mathrm{g}^{-1}$ dry wt. In contrast, in the rhizosphere the numbers of amoebae increased in the presence of $P$. pellio from 6000 to 55000 ind. $\mathrm{g}^{-1}$ dry wt and the abundance of naked amoebae was at a maximum in rhizosphere soil with nematodes and earthworms present (88 900 ind. $\mathrm{g}^{-1}$ dry wt). Also, flagellate numbers depended on both the presence of nematodes and earthworms. With nematodes present, the number of 
flagellates increased by a factor of 3.6 from 3100 to 11200 ind. $\mathrm{g}^{-1}$ dry wt. In contrast, flagellate numbers decreased by ca. $50 \%$ from 8000 to 4300 ind. $\mathrm{g}^{-1}$ dry wt in presence of earthworms with the negative effect of earthworms being compensated for by nematodes [2].

There are only few studies on microfauna-arthropod interactions, but many of the microarthropods generally considered as saprophagous may in fact be omnivorous. Mite species which were supposed to be fungal feeders may also prey on nematodes [128] and possibly protozoa [127]. Predatory microarthropods feeding on nematodes and other microarthropods may also ingest fungal hyphae $[64,91]$. Brussaard et al. [14] found that nitrogen mineralization was significantly increased by the bacterivorous mite Histiostoma litorale and by the bacterivorous nematode Acrobeloides buetschlii in microcosms containing sterilized soil amended with luzerne meal and inoculated with a soil suspension containing a mix of bacteria and protozoa. Whether these effects were caused by microfaunal grazing or by a stimulation of the protozoa remained unresolved. However, Vreeken-Buijs et al. [126] found no stimulation of a naked amoebae (Acanthamoeba sp.) by the bacterivorous mite $H$. litorale and concluded that the lower nitrogen mineralization in treatments with mites was due to the low production rate of mites.

The data show that apart from predation of soil microbes by microfaunal grazers, the microfaunal community is embedded in a complex network of faunal interactions. Thus, the 'microbial loop' in soil is in fact a microbial food-web and complicated animal interactions determine the overall effects of microbial grazers on the microflora and subsequent nutrient mineralization.

\section{CONCLUSIONS}

Competition between plants is high, because plant growth in natural environments frequently takes place in dense stands of established vegetation. Thus both, beneficial and deleterious associations of plants with micro-organisms and the regulation of these associations by soil faunal activity may be of fundamental importance for individual plant species, but also for the species composition of the whole community.

Rhizosphere processes are driven by large quantities of photosynthetically fixed carbon which are either directly transferred to symbionts as mycorrhizal fungi, or released as root exudates stimulating rhizosphere bacterial growth. Nematode-mycorrhiza interactions show that faunal interactions may induce physiological changes in both, the plant itself and its mycorrhizal symbiont. Similar effects may be induced by other fungivorous groups of the soil fauna, but the knowledge on the significance of these interactions is sparse. In contrast to the plant-mycorrhiza symbiosis, little attention has been paid to rhizosphere bacteria. This is not surprising, since the relationship between bacteria and plant roots is less obvious than that between plants and mycorrhizae. However, it has been stressed by soil microbiologists that beneficial and deleterious rhizosphere bacteria may significantly affect plant growth $[15,38,86,107,110]$. Due to the dual effect of root exudates, fueling a diverse bacterial population and intensifying the competition for nutrients between plants and micro-organisms, the interaction between rhizosphere bacteria and plant roots can only be understood by considering microfaunal predators [27, 30]. However, until now, exchange of thought and co-operation between the different disciplines investigating rhizosphere organisms is scarce. The view of plant physiologists is still focused on chemical exchange processes of nutrients in the rhizosphere [84]. Similarly, soil microbiologists tend to neglect the existence of microfaunal-microbial interactions, or consider them only to be important in respect to plant pathogens. Soil zoologists tend to neglect the diversity of rhizosphere organisms by focusing on faunal effects on microbial biomass. Only recently the importance of microfaunal grazing not only for N-release from microbial biomass but also for the composition of the bacterial community in the rhizosphere and the production of plant hormones has been considered [54, $56,71]$. Thus microfaunal predators, especially protozoa seem to be more closely involved in rhizosphere interactions than previously assumed. In the past, plant physiologists, soil zoologists and soil microbiologists have focused on direct effects of micro-organisms and soil animals on rhizosphere processes. However, due to the complex structure of animal-microbial-plant interactions, indirect effects presumably are also of crucial importance.

Although there is striking evidence for the significance of microbial-microfaunal interactions enhancing plant growth, the mechanisms are poorly understood. The picture of the role of carbon resources released by plant roots into the rhizosphere for the functioning of the rhizosphere community remains vague. In addition to the well established plant-mycorrhiza symbiosis, plant growth is also significantly influenced by a mutualistic relationship with the bacterial feeding microfauna in the rhizosphere, especially with protozoa. There is increasing evidence that microfaunal grazing selectively favours certain microflora species, altering the microbial diversity and the microbial catabolic activity. However, it is unknown whether protozoan grazing favours deleterious or beneficial rhizosphere micro-organisms and whether effects vary between protozoan species. Also it is likely that microfaunal effects on plant growth differ among plant species. As plant species have evolved different strategies for nutrient acquisition, and not all plant species rely on the symbiotic relationship with mycorrhiza, it is likely that plants benefit to a different degree from the mutualistic relationship with protozoa.

To unravel the complex microbial-faunal interactions in the rhizosphere, further research on rhizosphere processes requires a multidisciplinary approach 
and an interdisciplinary exchange of knowledge between plant physiologists, soil scientists, microbiologists and zoologists leading to a deeper understanding of rhizosphere processes that regulate mineralization, nutrient cycling and plant growth.

For many years ecologists have viewed soil organisms and plants as relatively independent from each other. However, much of the evidence presented in this review suggests that differences in plant growth in the field can only be understood in relation to microbialfaunal interactions in the rhizosphere.

\section{REFERENCES}

[1] Allen M.F., The Ecology of Mycorrhizae, Cambridge University Press, Cambridge, 1991.

[2] Alphei J., Bonkowski M., Scheu S., Protozoa, Nematoda and Lumbricidae in the rhizosphere of Hordelymus europaeus (Poaceae): Faunal interactions, response of microorganisms and effects on plant growth, Oecologia 106 (1996) 111-126.

[3] Anderson J.P.E., Domsch K.H., A physiological method for the quantitative measurement of microbial biomass in soils, Soil Biol. Biochem. 10 (1978) 215-221.

[4] Anderson R.V., Elliott E.T., McClellan J.F., Coleman D.C., Cole C.V., Hunt H.W., Trophic interactions in soils as they affect energy and nutrient dynamics. III. Biotic interactions of bacteria, amoebae, and nematodes, Microb. Ecol. 4 (1978) 361-371.

[5] Anderson T.R., Patrick Z.A., Mycophagous amoeboid organisms from soil that perforate spores of Thielaviopsis basicola and Cochliobolus sativus, Phytopathology 68 (1978) 1618-1626.

[6] Azcón R., Selective interaction between free-living rhizosphere bacteria and vesicular-abuscular mycorrhizal fungi, Soil Biol. Biochem. 21 (1989) 639-644.

[7] Bamforth S.S., The role of protozoa in litters and soil, J. Protozool. 32 (1985) 404-409.

[8] Bardgett R.D., Wardle D., Yeates G.W., Linking above-ground and below-ground interactions: how plant responses to foliar herbivory influence soil organisms, Soil Biol. Biochem. 30 (1998) 1867-1878.

[9] Beare M.H., Coleman D.C., Crossley D.A., Hendrix P.F., Odum E.P., A hierarchical approach to evaluating the significance of soil biodiversity to biogeochemical cycling, Plant Soil 170 (1995) 5-22.

[10] Bonkowski M., Protozoen und Lumbriciden in einem Kalkbuchenwald: Untersuchungen zur Interaktion von Populationen der Bodenfauna und ihrer Wirkung auf Stoffdynamik und Pflanzenwachstum, Ber. Forschungszentr. Waldökosyst. Göttingen A134 (1996) $1-133$.

[11] Bouwman L.A., Zwart K.B., The ecology of bacterivorous protozoa and nematodes in arable soil, Agric. Ecosyst. Environ. 51 (1994) 145-160.

[12] Brown M.E., Plant growth substances produced by microorganisms of soil rhizosphere, J. Appl. Bacteriol. 35 (1972) 443-451.
[13] Brown M.E., Rhizosphere microorganisms - opportunists, bandits or benefactors, in: Walker N. (Ed.), Soil Microbiology, Butterwarths, London, 1975, pp. 21-38.

[14] Brussaard L., Noordhuis R., Geurs M., Bouwman L.A., Nitrogen mineralization in soil in microcosms with or without bacterivorous nematodes and nematophagous mites, Acta Zool. Fenn. 196 (1995) $15-21$.

[15] Burr T.J., Caesar A., Beneficial plant bacteria, Crit. Rev. Plant Sci. 2 (1984) 1-20.

[16] Carling D.E, Roncadori R.W., Hussey R.S., Interactions of arbuscular mycorrhizae, Meloidogyne arenaria, and phosphorus fertilization on peanut, Mycorrhiza 6 (1996) 9-13.

[17] Caron D.A., Grazing of attached bacteria by heterotrophic microflagellates, Microb. Ecol. 13 (1987) 203-218.

[18] Chakraborty S., Theodorou C., Bowen G.D., The reduction of root colonization by mycorrhizal fungi by mycophagous amoebae, Can. J. Microbiol. 31 (1985) 295-297.

[19] Cheng W., Coleman D.C., A simple method for measuring $\mathrm{CO}_{2}$ in a continuous air flow system: modifications to the substrate-induced respiration technique, Soil Biol. Biochem. 21 (1989) 385-388.

[20] Cheng W., Virginia R.A., Measurement of microbial biomass in arctic tundra soils using fumigationextraction and substrate-induced respiration procedures, Soil Biol. Biochem. 25 (1993) 135-141.

[21] Cheng W., Coleman D.C., Carroll C.R., Hoffman C.A., In situ measurement of root respiration and soluble carbon concentrations in the rhizosphere, Soil Biol. Biochem. 25 (1993) 1189-1196.

[22] Cheng W., Zhang Q., Coleman D.C., Carroll C.R., Hoffman C.A., Is available carbon limiting microbial respiration in the rhizosphere? Soil Biol. Biochem. 28 (1996) 1283-1288.

[23] Clarholm M., Protozoan grazing of bacteria in soil impact and importance, Microb. Ecol. 7 (1981) 343-350.

[24] Clarholm M., Microbes as predators or prey - Heterotrophic, free-living protozoa: neglected microorganisms with an important task in regulating bacterial populations, in: Klug M.J., Reddy C.A. (Eds.), Current Perspectives on Microbial Ecology, American Society of Microbiology, Washington, 1984, pp. 321-326.

[25] Clarholm M., Interactions of bacteria, protozoa and plants leading to mineralization of soil nitrogen, Soil Biol. Biochem. 17 (1985) 181-187.

[26] Clarholm M., Possible roles for roots, bacteria, protozoa and fungi in supplying nitrogen to plants, in: Fitter A.H. (Ed.), Ecological Interactions in Soil: Plants, Microbes and Animals, Blackwell Scientific Publ., Oxford, 1985, pp. 355-365.

[27] Clarholm M., The microbial loop in soil, in: Ritz K., Dighton J., Giller K.E. (Eds.), Beyond the Biomass, Wiley-Sayce, Chichester, 1994, pp. 221-230.

[28] Cole C.V., Elliott E.T., Hunt H.W., Coleman D.C., Trophic interactions as they affect energy and nutrient dynamics. V. Phosphorus transformations, Microb. Ecol. 4 (1978) 381-387. 
[29] Coleman D.C., Through a ped darkly: an ecological assessment of soil-root-microbial-faunal interactions, in: Fitter A.H., Atkinson D., Read D.J., Usher M.B. (Eds.), Ecological Interactions in Soil, Blackwell, Oxford, 1985, pp. 1-21.

[30] Coleman D.C., Reid C.P.P., Cole C.V., Biological strategies of nutrient cycling in soil systems, Adv. Ecol. Res. 13 (1983) 1-55.

[31] Coleman D.C., Anderson R.V., Cole C.V., Elliott E.T., Woods L., Campion M.K., Trophic interactions in soil as they affect energy and nutrient dynamics. IV. Flows of metabolic and biomass carbon, Microb. Ecol. 4 (1978) 373-380.

[32] Coleman D.C., Cole C.V., Anderson R.V., Blaha M., Campion M.K., Clarholm M., Elliott E.T., Hunt H.W., Shaefer B., Sinclair J., An analysis of rhizospheresaprophage interactions in terrestrial ecosystems, Ecol. Bull. (Stockholm) 25 (1977) 299-309.

[33] Cromack K., Fichter B.L., Moldenke A.M., Entry J.A., Ingham E.R., Interactions between soil animals and ectomycorrhizal fungal mats, Agric. Ecosyst. Environ. 24 (1988) 161-168.

[34] Darbyshire J.F., Greaves M.P., Bacteria and protozoa in the rhizosphere, Pestic. Sci. 4 (1973) 349-360.

[35] Dash M.C., Cragg J.B., Selection of microfungi by Enchytraeidae (Oligochaeta) and other members of the soil fauna, Pedobiologia 12 (1972) 282-286.

[36] De Ruiter P.C., Moore J.C., Zwart K.B., Bouwman L.A., Hassink J., Bloem J., De Vos J.A., Marinissen J.C.Y., Didden W.A.M., Lebbink G., Brussaard L., Simulation of nitrogen mineralization in the below ground food webs of two winter wheat fields, J. Appl. Ecol. 30 (1993) 95-106.

[37] Deacon J.W., Modern Mycology, Blackwell, London, 1997, pp. 268-272.

[38] Devevre O., Garbaye J., Perrin R., Experimental evidence of a deleterious soil microflora associated with Norway spruce decline in France and Germany, Plant Soil 148 (1993) 145-153.

[39] Didden W., Ecology of terrestrial Enchytraeidae, Pedobiologia 37 (1993) 2-29.

[40] Ek H., Sjögren M., Arnebrant K., Söderström B., Extramatrical mycelial growth, biomass allocation and nitrogen uptake in ectomycorrhizal systems in response to collembolan grazing, Appli. Soil Ecol. 1 (1994) 155-169.

[41] Ekelund F., Enumeration and abundance of mycophagous protozoa in soil, with special emphasis on heterotrophic flagellates, Soil Biol. Biochem. 30 (1998) 1343-1347.

[42] Ekelund F., Rønn R., Notes on protozoa in agricultural soil with emphasis on heterotrophic flagellates and naked amoebae and their ecology, FEMS Microbiol. Rev. 15 (1994) 321-353.

[43] Elliott E.T., Coleman D.C., Cole C.V., The influence of amoebae on the uptake of nitrogen by plants in gnotobiotic soil, in: Harley J.L., Russell R.S. (Eds.), The Soil-Root Interface, Academic Press, London, 1979, pp. 221-229.

[44] Finlay R.D., Interactions between soil microarthropods and endomycorrhizal associations of higher plants, in: Fitter A.H., Atkinson D., Read D.J., Usher M.B. (Eds.), Ecological Interactions in Soil, Blackwell, Oxford, 1985, pp. 319-331.

[45] Fitter A.H., Sanders I.R., Interactions with the soil fauna, in: Allen M.F. (Ed.), Mycorrhizal Functioning, Chapman and Hall, London, 1992, pp. 333-354.

[46] Fogel R., Roots as primary producers in below ground ecosystems, in: Fitter A.H. (Ed.), Ecological Interactions in Soil, Blackwell Scientific Publ., Oxford, 1985, pp. 23-36.

[47] Foissner W., Soil protozoa: fundamental problems, ecological significance, adaptations in ciliates and testaceans, bioindicators, and guide to the literature, Progr. Protistol. 2 (1987) 69-212.

[48] Freckman D.W., Nematodes in Soil Ecosystems, University of Texas Press, Austin USA, 1982.

[49] Giannakis N., Sanders F.E., Interactions between mycophagous nematodes, mycorrhizal and other soil fungi, Agric. Ecosyst. Environ. 29 (1990) 163-167.

[50] Giller P.S., The diversity of soil communities, the 'poor man's tropical rainforest', Biodiv. Conserv. 5 (1996) 135-168.

[51] Griffiths B.S., Mineralization of nitrogen and phosphorus by mixed cultures of the ciliate protozoan Colpoda steinii, the nematode Rhabditis sp. and the bacterium Pseudomonas fluorescens, Soil Biol. Biochem 18 (1986) 637-641.

[52] Griffiths B.S., Enhanced nitrification in the presence of bacteriophagous protozoa, Soil Biol. Biochem. 21 (1989) 1045-1051.

[53] Griffiths B.S., Soil nutrient flow, in: Darbyshire J.F. (Ed.), Soil Protozoa, CAB International, Wallingford, 1994, pp. 65-91.

[54] Griffiths B.S., Bardgett R.D., Interactions between microbe-feeding invertebrates and soil microorganisms, in: van Elsas J.D., Trevors J.T., Wellington E.M.H. (Eds.), Modern Soil Microbiology, Marcel Dekker, New York, 1997, pp. 165-182.

[55] Griffiths B.S., Robinson D., Root-induced nitrogen mineralization: A nitrogen balance model, Plant Soil 139 (1992) 253-263.

[56] Griffiths B.S., Bonkowski M., Dobson G., Caul S., Changes in soil microbial community structure in the presence of microbial-feeding nematodes and protozoa, Pedobiologia 43 (1999) 297-304.

[57] Harley J.L., Smith S.E., Mycorrhizal Symbiosis, Academic Press, London, 1983.

[58] Harris K.K., Boerner R.E.J., Effects of below-ground grazing by collembola on growth, mycorrhizal infection and $\mathrm{P}$ uptake of Geranium robertianum, Plant Soil 129 (1990) 203-210.

[59] Heal O.W., Soil fungi as food for amoebae, in: Doeksen J., van der Drift I. (Eds.), Soil Organisms, North Holland, Amsterdam, 1963, pp. 289-297.

[60] Hekmann W.E., Van Den Boogert P.J.H.F., Zwart K.B., The physiology and ecology of a novel, obligate mycophagous flagellate, FEMS Microbiol. Ecol. 86 (1992) 255-265.

[61] Hiol F., Dixon R.K., Curl E.A., The feeding preference of mycophagous Collembola varies with the ectomycorrhizal symbiont, Mycorrhiza 5 (1994) 99-103. 
[62] Holland J.N., Cheng W., Crossley D.A. Jr, Herbivoreinduced changes in plant carbon allocation: assessment of below-ground C fluxes using carbon-14, Oecologia 107 (1996) 87-94.

[63] Ingham E.R., Massicotte H.B., Protozoan communities around conifer roots colonized by ectomycorrhizal fungi, Mycorrhiza 5 (1994) 53-61.

[64] Ingham E.R., Trofymow J.A., Ames R.N., Hunt H.W., Morley C.R., Moore J.C., Coleman D.C., Trophic interactions and nitrogen cycling in a semi-arid grassland soil. 1. Seasonal dynamics of the natural populations, their interactions and effects on nitrogen cycling, J. Appl. Ecol. 23 (1986) 597-614.

[65] Ingham R.E., Interactions between nematodes and vesicular-arbuscular mycorrhizae, Agric. Ecosyst. Environ. 24 (1988) 169-182.

[66] Ingham R.E., Detling J.K., Plant-herbivore interactions in a North American mixed-grass prairie. III. Soil nematode populations and root biomass on Cynomys ludovicianus colonies and adjacent uncolonized areas, Oecologia 63 (1984) 307-313.

[67] Ingham R.E., Detling J.K., Effects of defoliation and nematode consumption on growth and leaf gas exchange in Bouteloua curtipendula, Oikos 46 (1986) 23-28.

[68] Ingham R.E., Trofymow J.A., Ingham E.R., Coleman D.C., Interactions of bacteria, fungi, and their nematode grazers: Effects on nutrient cycling and plant growth, Ecol. Monogr. 55 (1985) 119-140.

[69] Jaffee B.A., Population biology and biological control of nematodes, Can. J. Microbiol. 38 (1992) 359-364.

[70] Janssen M.P.M., Heijmans G.J.S.M., Dynamics and stratification of protozoa in the organic layer of a Scots pine forest, Biol. Fertil. Soils 26 (1998) 285-292.

[71] Jentschke G., Bonkowski M., Godbold D.L., Scheu S., Soil protozoa and plant growth: Nonnutritional effects and interaction with mycorrhizas, Biol. Fertil. Soils 20 (1995) 263-269.

[72] Kerry B.R., Crump D.H., Mullen L.A., Studies of the cereal cyst nematode, Heterodera avenae, under continuous cereals, 1975-1978 II. Fungal parasitism of female nematodes and eggs, Ann. Appl. Biol. 100 (1982) 489-499.

[73] Khan M.W., Nematodes Interactions, Chapman and Hall, London, 1993.

[74] Klironomos J.N., Kendrick W.B., Palatability of microfungi to soil arthropods in relation to the functioning of arbuscular mycorrhizae, Biol. Fertil. Soils 21 (1996) 43-52.

[75] Klironomos J.N., Ursic M., Density-dependent grazing on the extraradical hyphal network of the arbuscular mycorrhizal fungus, Glomus intraradices, by the collembolan, Folsomia candida, Biol. Fertil. Soils 26 (1998) 250-253.

[76] Kuikman P.J., Van Veen J.A., The impact of protozoa on the availability of bacterial nitrogen to plants, Biol. Fertil. Soils 8 (1989) 13-18.

[77] Kuikman P.J., Jansen A.G., Van Veen J.A., ${ }^{15}$ NNitrogen mineralization from bacteria by protozoan grazing at different soil moisture regimes, Soil Biol. Biochem. 23 (1991) 193-200.
[78] Kuikman P.J., Van Vuuren M.M.I., Van Veen J.A., Effect of soil moisture regime on predation by Protozoa of bacterial biomass and the release of bacterial nitrogen, Agric. Ecosyst. Environ. 27 (1989) 271-279.

[79] Kuikman P.J., Jansen A.G., Van Veen J.A., Zehnder A.J.B., Protozoan predation and the turnover of soil organic carbon and nitrogen in the presence of plants, Biol. Fertil. Soils 10 (1990) 22-28.

[80] Laheurte F., Berthelin J., Interactions between endomycorrhizas and phosphate solubilizing bacteria: effects on nutrition and growth of maize, in: GianinazziPearson V., Gianinazzi S. (Eds.), Physiological and Genetical Aspects of MycorrhizaeAspects physiologiques et génétiques des mycorrhizes, INRA, Paris, 1986, pp. 339-343.

[81] Larsen J., Jakobsen I., Effects of a mycophagous Collembola on the symbioses between Trifolium subterraneum and three arbuscular mycorrhizal fungi, New Physiol. 133 (1996) 295-302.

[82] Lavelle P., Faunal activities and soil processes: adaptive strategies that determine ecosystem function, Adv. Ecol. Res. 27 (1997) 93-132.

[83] Lingaraju S., Goswami B.K., Influence of a mycorrhizal fungus Glomus fasciculatum on the host: Parasite relationship of Rotylenchus reniformis in cowpea, Indian J. Nematol. 23 (1994) 137-141.

[84] Loneragan J.F., Plant nutrition in the 20th and perspectives for the 21st century, Plant Soil 196 (1997) 163-174.

[85] Lussenhop J., Collembola as mediators of microbial symbiont effects upon soybean, Soil Biol. Biochem. 28 (1996) 363-369.

[86] Lynch J.M., Plant growth regulators and phytotoxins from micro-organisms, in: Lynch J.M. (Ed.), Soil Biotechnology, Blackwell Scientific Publications, London, 1983, pp. 107-120.

[87] Maraun M., Migge S., Schaefer M., Scheu S., Selection of microfungal food by six oribatid mite species (Oribatida, Acari) from two different beech forests, Pedobiologia 42 (1998) 232-240.

[88] McGonigle T.P., Fitter A.H., Ecological consequences of arthropod grazing on VA mycorrhizal fungi, Proc. Soc. Edinb. 94B (1988) 25-32.

[89] McLean M.A., Kaneko N., Parkinson D., Does selective grazing by mites and colembola affect litter fungal community structure? Pedobiologia 40 (1996) 97-105.

[90] Moore J.C., The influence of microarthropods on symbiontic and non-symbiontic mutualism in detritalbased below ground food webs, Agric. Ecosyst. Environ. 24 (1988) 147-159.

[91] Moore J.C., Walter D., Hunt H.W., Arthropod regulation of micro- and meso-biota in below-ground detrital food webs, Ann. Rev. Entomol. Agron. 1 (1988) 234-238.

[92] Nikolyuk V.F., Some aspects of the study of soil protozoa, Acta Protozool. 7 (1969) 99-108.

[93] Nikolyuk V.F., Tapilskaja N.V., Bodenamöben als Produzenten von biotisch aktiven Stoffen, Pedobiologia 9 (1969) 182-187.

[94] Nurmihaho-Lassila E.-L., Timonen S., Haahtela K., Sen R., Bacterial colonization patterns of intact Pinus 
sylvestris mycorrhizospheres in dry pine forest soil: an electron microscopy study, Can. J. Microbiol. 43 (1997) 1017-1035.

[95] Old K.M., Giant soil amoebae cause perforation and lysis of spores of Cochliobolus sativus and Thielaviopsis basicola in natural soils, Can. J. Bot. 54 (1977) 2798-2809.

[96] Old K.M., Chakraborty S., Mycophagous soil amoebae: their biology and significance in the ecology of soil-borne plant pathogens, Progr. Protistol. 1 (1986) 163-194.

[97] Old K.M., Darbyshire J.F., Soil fungi as food for giant amoebae, Soil Biol. Biochem. 10 (1978) 93-100.

[98] Old K.M., Oros J.M., Mycophagous amoebae in Australian forest soils, Soil Biol. Biochem. 12 (1980) 169-175.

[99] Old K.M., Patrick Z.A., Giant soil amoebae: Potential biocontrol agents, in: Schippers B., Gams W. (Eds.), Soil-Borne Plant Pathogens, Academic Press, London, 1979, pp. 617-628.

[100] Paulitz T.C., Linderman R.G., Mycorrhizal interactions with soil organisms, in: Arora B., Rai D.K., Mukerji K.G., Knudsen G.R. (Eds.), Handbook of Applied Mycology, vol. 1, Marcel Dekker, New York, 1991, pp. 77-129.

[101] Petz W., Foissner W., Adam H., Culture, food selection and growth rate in the mycophagous ciliate Grossglockneria acuta Foissner, 1980: First evidence of autochthonous soil ciliates, Soil Biol. Biochem. 17 (1985) 871-875.

[102] Petz W., Foissner W., Wirnsberger W., Krautgartner W.D., Adam H., Mycophagy, a new feeding strategy in autochthonous soil ciliates, Naturwissenschaften 73 (1986) 560.

[103] Pussard M., Alabouvette C., Levrat P., Protozoan interactions with the soil microflora and possibilities for biocontrol of plant pathogens, in: Darbyshire J.F. (Ed.), Soil Protozoa, CAB International, Wallingford, 1994, pp. 123-146.

[104] Ridsdill Smith T.J., Effects of root-feeding by scarabaeid larvae on growth of perennial ryegrass plants, J. Appl. Ecol. 14 (1977) 73-80.

[105] Ritz K., Griffiths B.S., Effects of carbon and nitrate additions to soil upon leaching of nitrate, microbial predators and nitrogen uptake by plants, Plant Soil 102 (1987) 229-237.

[106] Robinson D., Griffiths B.S., Ritz K., Wheatley R., Root induced nitrogen mineralization: A theoretical analysis, Plant Soil 117 (1989) 185-193.

[107] Sarwar M., Kremer R.J., Enhanced suppression of plant growth through production of L-tryptophanderived compounds by deleterious rhizobacteria, Plant Soil 172 (1995) 261-269.

[108] Schaefer M., Schauermann J., The soil fauna of beech forests: comparison between a mull and a moder soil, Pedobiologia 34 (1990) 299-314.

[109] Schlegel H.G., Allgemeine Mikrobiologie, Thieme, Stuttgart, 1985.

[110] Shishido C.P., Chanway C.P., Forest soil community responses to plant growth-promoting rhizobacteria and spruce seedlings, Biol. Fertil. Soils 26 (1998) 179-186.
[111] Singh Y.P., Singh R.S., Sitaramaiah K., Mechanism of resistance of mycorrhizal tomato against root-knot nematode, in: Jalali B.L., Chand H. (Eds.), Trends in Mycorrhizal Research, Proceedings of the National Conference on Mycorrhiza, Haryana Agricultural University, Hissar, 1990, pp. 96-97.

[112] Smith G.S., Interactions of nematodes with mycorrhizal fungi, in: Vecch J.A., Dickson D.W. (Eds.), Vistas on Nematology, Society of Nematologists, Hyattsville, 1987, pp. 292-300.

[113] Smith S.E., Gianinazzi-Pearson V., Physiological interactions between symbionts in vesicular arbuscular mycorrhizal plants, Ann. Rev. Plant Physiol. Mol. Biol. 39 (1988) 221-244.

[114] Smith S.E., Read D.J., Mycorrhizal symbiosis, 2nd ed., Academic Press Ltd., London, 1997.

[115] Sohlenius B., Abundance, biomass and contribution to energy flow by soil nematodes in terrestrial ecosystems, Oikos 34 (1980) 186-194.

[116] Stanton N.L., The effect of clipping and phytophagous nematodes on net primary production of blue grama, Bouteloua gracilis, Oikos 40 (1983) 249-257.

[117] Tapilskaja N.V., Amoeba albida Nägler und ihre Beziehungen zu dem Pilz Verticillum dahliae Kleb, dem Erreger der Welkekrankheit von Baumwollpflanzen, Pedobiologia 7 (1967) 156-165.

[118] Taylor W.D., Berger J., Growth responses of cohabiting ciliate protozoa to various prey bacteria, Can. J. Zool. 54 (1976) 1111-1114.

[119] Thimm T., Larink O., Grazing preferences of some collembola for endomycorrhizal fungi, Biol. Fertil. Soils 19 (1995) 266-268.

[120] Tylka G.L., Hussey R.S., Roncadori R.W., Interactions of vesicular-arbuscular mycorrhizal fungi, phosphorus, and Heterodera glycines on soybean, J. Nematol. 23 (1991) 122-133.

[121] Umesh K.C., Krishnappa K., Bagyaraj D.J., Interactions of burrowing nematode, Radopholus similis (Cobb 1893) Thorne and VA mycorrhiza Glomus fasciculatum (Thaxt) Gerd and Trappe in banana (Musa acuminata Colla.), Indian J. Nematol. 18 (1988) (1949) 6-11.

[122] Usher M.B., Davis P., Harris J., Longstaff B., A profusion of species? Approaches towards understanding the dynamics of the populations of microarthropods in decomposer communities, in: Anderson R.M., Turder B.D., Taylor L.R. (Eds.), Population Dynamics, Blackwell Scientific, Oxford, 1979, pp. 359-384.

[123] Venette R.C., Ferris H., Influence of bacterial type and density on population growth of bacterial-feeding nematodes, Soil Biol. Biochem. 30 (1998) 949-960.

[124] Verhagen F.J.M., Lanbroek H.J., Effects of grazing by flagellates on competition for ammonium between nitrifying and heterotrophic bacteria in chemostats, Appl. Environ. Microbiol. 58 (1992) 1962-1969.

[125] Verhagen F.J.M., Duyts H., Laanbroek H.J., Effects of grazing by flagellates on competition for ammonium between nitrifying and heterotrophic bacteria in soil columns, Appl. Environ. Microbiol. 59 (1993) 2099-2106. 
[126] Vreeken-Buijs M.J., Geurs M., de Ruiter P.C., Brussaard L., The effects of bacterivorous mites and amoebae on mineralization in a detrital based belowground food web; microcosm experiment and simulation of interactions, Pedobiologia 41 (1997) 481-493.

[127] Walter D.E., Kaplan D.T., Feeding observations on two astigmatid mites, Schwiebia rocketii (Acaridae) and Histioma bakeri (Histiomatidae) associated with Citrus feeder roots, Pedobiologia 34 (1990) 281-286.

[128] Walter D.E., Hugens P.A., Freckman D.W., Consumption of nematodes by fungivorous mites, Tyrophaggus spp. (Acarina: Astigmata: Acaridae), Oecologia 70 (1986) 357-361.

[129] Warnock A.J., Fitter A.H., Usher M.B., The influence of a springtail Folsomia candida (Insecta: Collembola) on the mycorrhizal association of leek, Allium porrum, and the vesicular-arbuscular mycorrhizal endophyte Glomus fasciculatus, New Phytol. 90 (1982) 285-292.

[130] Weekers P.H.H., Bodelier P.L.E., Wijen J.P.H., Vogels G.D., Effects of grazing by the free-living soil moebae Acanthamoeba castellanii, Acanthamoeba polyphaga, and Hartmanella veriformis on various bacteria, Appl. Environ. Microbiol. 59 (1993) 2317-2319.

[131] Winkler H.E., Hetrick B.A.D., Todd T.C., Interactions of Heterodera glycines, Macrophomina phaseolina, and mycorrhizal fungi on soybean in Kansas, J. Nematol. 26 (1994) 675-682.

[132] Woods L.E., Cole C.V, Elliott E.T., Anderson R.V., Coleman D.C., Nitrogen transformations in soil as affected by bacterial-microfaunal interactions, Soil Biol. Biochem. 14 (1982) 93-98.

[133] Yeates G.W., Soil nematodes in terrestrial ecosystems, J. Nematol. 11 (1979) 213-229.

[134] Zunke U., Perry R.N., Nematodes: harmful and beneficial organisms, in: Benckiser G. (Ed.), Fauna in Soil Ecosystems, Marcel Dekker, New York, 1997, pp. 85-133.

[135] Zwart K.B., Kuikman P.J., Van Veen J.A., Rhizosphere protozoa: their significance in nutrient dynamics, in: Darbyshire J.F. (Ed.), Soil Protozoa, CAB International, Wallingford, 1994, pp. 93-122. 